\title{
Some Aspects of Marine Carbonate Masses from the Paleoecological Point of View
}

By

Takashi HAMADA

\begin{abstract}
Bioreef is a site of the highest diversity of biota on the earth's surface. Geohistorically, however, it was a sort of fairly simple mound in the Precambrian Era as exemplified by a stromatolitic hump. The early Cambrian archaeocyathid reef was monotonous but the first true bioreef made by calcium carbonate-secreting marine animals. The Paleozoic and later coral reefs have been much amplified in their constitutions through ages. It was stressed that the ecological reefs should clearly be distinguished from the stratigraphic ones by paleoecological analysis.

The bioreef is here subdivided into four main ecological types, i.e. the isolated island type, the plateau island type, the continental shelf type and the shelf margin type. They are characterized by respective grades of development of the skirts that frill the reefs. Bioreefs formed on a shallow and wide shelf like the Great Barrier Reef are associated with well-developed inter-reef or back-reef type stagnant basins which bear a high potentiality of metamorphism of the organic materials derived from the reef biota into petroleum. Excretion and bioerosion of reef inhabitants are described as the important agencies of a biochemical activity for destructive and diagenetic processes of the reefs.

Finally, a hypothetical classification of several limestone bodies in Japan is proposed on the basis of paleoecological megastructures of these carbonate sediments.
\end{abstract}

\section{1. まえがき}

新しい油槽構造として近年大きな脚光を浴びている炭 酸塩岩体の系統的な研究は, わが国においてやや扔くれ がみられることは否定できない。それは日本の産油層に ほとんどそうした例がなく，外国での事例を理解する下 地すら欠いていたからであろら。炭酸塩岩体の発達とい らものは, 地質年代の広がりからも, 地域的な発展状況 からしても非常に広範囲にわたるものであり, その研究 には多方面からのアプローチが要求される。とりわけ総 合的な判断・評価のためには, 最も基本となる構成要素 としての古生物, あるいはその環境復元に欠かすことが できない古生態学の立場が重要視されなければならない ことはいうまでもない。

この小論では，筆者の少ない経験の中だけからあえて わがままな発想を許していただき，1つの問題提起とし て,こうした炭酸塩岩体をグロスの古生態学的対象とし

昭和 52 年 9 月 20 日受理

* 昭和 52 年度石油技術協会総会シンポジウム講演に若干補足

** 東京大学教裳学部宇宙地球科学教室 石油技術協会誌 Vol.42 No.6 (1977)
てとりあげてみたい。文献を網羅したわけでもなくま た具体例を示すものでもないが，一応の小文にまとめて 大方のご批判を仰ぎたいと思う。

本論に入る前に, シンポジウム講演に当たって大变抒 世話をいただいた河井興三教授，星野一男博士ならびに 関係各位に対し，誌面を借りて厚く和礼申し上げる。

\section{2. 礁 の 定 義}

礁（reef）とは本来地形上の用語であり，水中なかん づく海底に㨟いて周辺より突出した高まりを指してい る。そしてその高まりを構成する主要な物質の種類によ って，岩礁，カキ礁，サンゴ礁などと区別されている が，これが地質学的な用語として転用される場合は，多 少なりともニュアンスが違ってきている。すなわち，現 在の地形としての突出部は形態そのもを認識し易く, 誤 解を招く抢それはまずないであろう。しかし，地質時代 の過去のそれらについては，ある瞬間の時間断面におい てはたして本当に地形的高まりであったのか，それとも 長期間の堆積作用を通じて周辺と区別されるよらな岩体 を結果せしめているのか，といった識別が 先決となる 
（浜田，1975，第 2 図）。

古生態学的には，らつう原初から突出地形であったも のを狭義の礁, つまり生礁 (bioreef あるいは ecological reef）と呼び，そうでない地層の集合形態としての塊状 岩塊を層礁 (stratigraphic reef) と称している。これらを 地層それ自体に則して表現するならば，前者が bioherm， 後者が biostrome といらことになる。このような分類 は，どちらかといえば概念的なものであって，具体的な 事象にはもっと複雑でいろいろの組み合わせによるケー スが存在するのであり，もら少し詳しく突込んだ取扱い が必要となることはいらまでもない。

第 1 図炭酸塩岩体の型の例
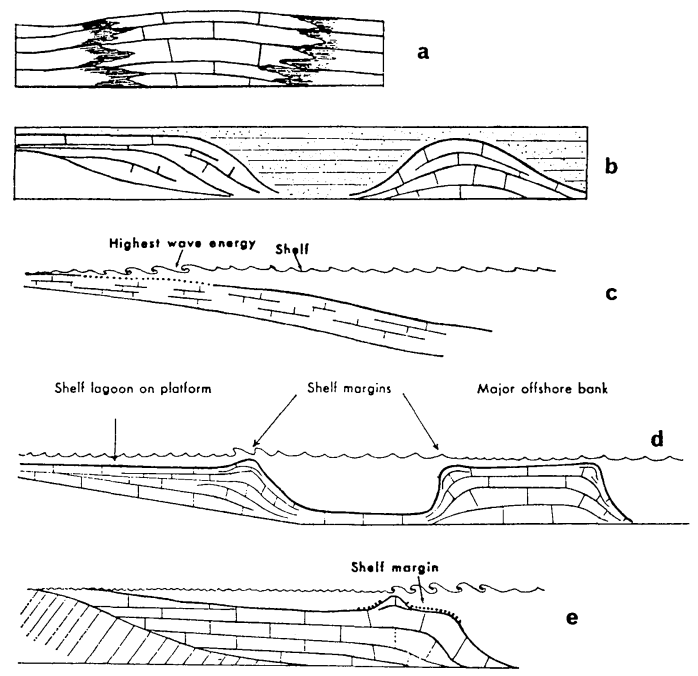
a : carbonate mass (stratigraphic reef)
b : carbonate buildups (bio-reef)
c: carbonate ramp (shelf 型)
d : lagoon, shelfmargin, offshore bank
$\mathrm{e}$ ： d 図左側の拡大，platform 縁に打ける局所
的 buildup.
(Wilson, 1975, figs. II-1 3 より)

例えば第 1 図 $\mathrm{a} \sim \mathrm{e}$ に示したような各型は，そのわか り易い表現であろうと思われる。a は形態的にいえば biostrome，つまり等時線が地層面とほぼ平行であって， 時間の経過と局所的な炭酸塩の集積との組み合わせのた めに，結果としての形態が礁となっているもので，ここ ではは単に carbonate mass として成因的な呼称をさけ ている。一般に，層礁の場合は貝殼片などが運搬されて きてできるので，形成された炭酸塩岩類の粒度組成は礫 〜砂サイズのものとなり，粗しよらではあるが，現地性 の構造生礁にくらべるとより密になっている。

\section{3. 生礁の地史的变遷}

さて小論では主として生礁をとりあげることとし，ま
ずその地史的背景を明らかにしておきたい。

生物が海中で礁を形成するためには，何らかの手段で 特定箇所への物質の凝集を達成しなければならないこと はいらまでもない。生物そのものがその素材となるか, あるいは素材を他に求め, 生物の働きによってそれを利 用するかの 2 つの方法があろう。前者の典型がいわゆる サンゴ礁であり, 生礁の大部分がその範疇に属してい る。一方, 後者型の礁はむしろ特殊であって, 先カンブ リア時代のようにまだ無殼生物しかいなかった時期に重 要性をもつものである。

例えば，世界各地の先カンブリア界に比較的普遍的に 見出されるストロマトライト (stromatolites)が後者タイ プの代表格である。顕生累代に入ってからは, 底生動物 の増加のために微成層構造を乱される機会が多くなり, ストロマトライトが法とんど見られなくなってしまう。 しかし現生ではバハマ礁の一部やオーストラリア西岸の シャークベイの一部 (LOGAN ら，1964など) の，きわ めて限定された環境にのみその形成が認められる。この ストロマトライト礁形成のメカニズムとしては, 主とし て藍藻類のような原始的藻類がフィルム状の群落をつく り，そこへ底質の炭酸塩砂粒などがトラップされて，潮 の干満のたびに 1 層づつ層を重ねていくものであるとい うことが明らかにされてきた。でき上ったストロマトラ イト構造中には軟組織は残されないために，外観のみの 層理が発達することとなり, かつては生物起源論者と無 機成因論者との間でのはげしい論争の種になった。した がって，このような構造は純粋の生礁とはいい難いけれ ども, 生物活動が主たる原因となっている堆積構造の 1 つであるとして, 化石でもなく堆積物プロパーでもない， いわば中間的な特例と考えればよい。このようなストロ マトライト生礁は, 先カンブリア時代後半にとくに大規 模の発達をとげており，例えばカナダの Minto Archに は，厚さ $10 \mathrm{~m}$ 以上もの炭酸塩岩層がまったくこの構造の みによって形造られている(YOUNG \& LONG, 1976)。

顕生累代に入って多くの海生無脊椎動物が有殼となっ て，とくに群体を形成しさらに炭酸カルシウムを骨格や 外殸に用いる生物が増加してくると，そこにいわゆる複 合生礁としてのコンプレックスがつくられるようにな る。これらの礁のらち, 最も単純な原型が, カンブリア 紀前期にのみ発達した古杯類礁（アーケオシアタス礁）

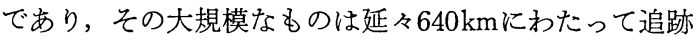
されるという。

カンブリア紀後期には, すでに原始的な四射サンゴ類 が出現ししており，礁には至らないまでも小群落を形成 している（JELL \& JELL, 1976)。続くオルドビス紀に は床板サンゴが繁栄し, それらに苔虫類などの群体も参 
第 1 表 代表的生礁の地史的変遷

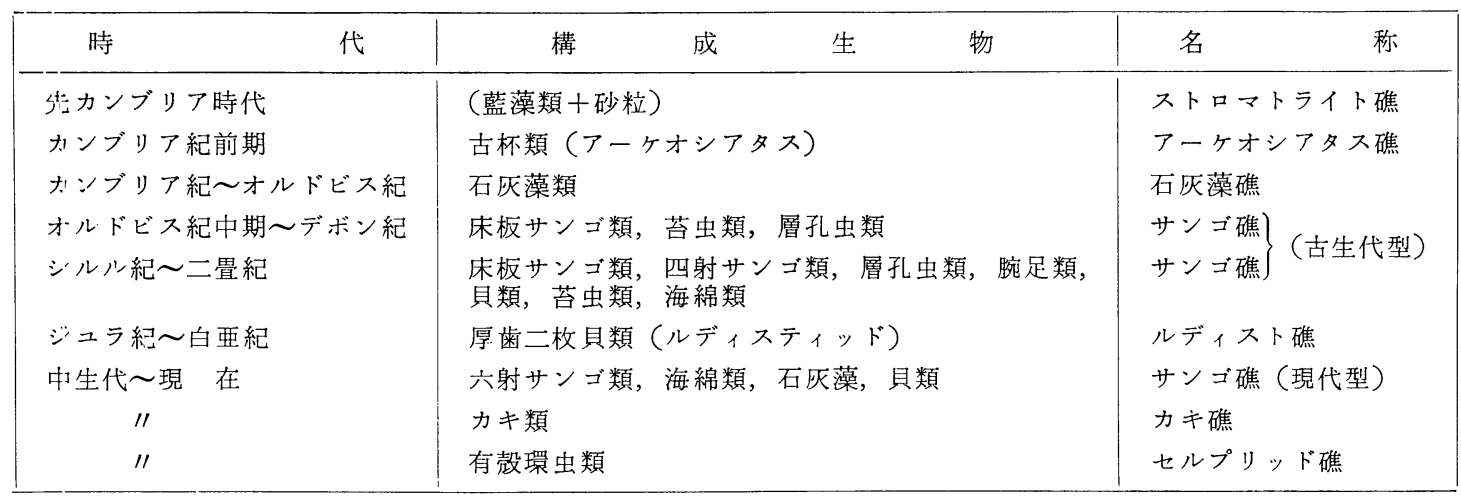

加してて,ここに明瞭な複合生礁が出現する。

オルドビス紀以後は, 四射サンゴ類が絶えたあと六射 サン゙ゴ類というように, 構成主体の生物の分類群に変化 が抗こることがあっても, 基本的な生態学的パターンは むしろ一定となり, 現在のサンゴ礁にまで到達するので ある。要は, 先カンブリア時代のストロマトライト期か 巨始まった生物活動による礁形成が，カンブリア紀のア 一ケオシアタス単純礁からその後の種々の複合礁に至る という, 一連の, しかも単純から複雑へといった生礁の 変遷史をもつ点をみておくことである。

現在のサンゴ礁は, 熱帯〜亜熱帯において生じる地球 上で最高の生物学的多様性をもつ部分であり, 多くの動 植物がそこに 1 つ系をなしながら関与しているもので ある。地質時代においても事情はおそらく大差なかった と考えられ, 生礁部分は周辺の生物相に比して一段之複 雑かつ多様性の高い生態系をなしていたとみられる。だ からそれ自身が時代とともにさらに複雑化していく現象 は, 生物種の進化に対応する生態系の進化と考兄てょ い。しかし，その一方，若い地質時代にあっても特殊な 生態学的環境においては, ルディスト礁やカキ礁のよう に単純群集からなる生礁もまた存在し, それらはそれら なりに古環境を示すよい示標として役立っている。

\section{4. 生礁の形態と環境}

生礁の形態分類にはすでにいくつもの例があって, そ れぞれの立場で有効に用いられている。しかしここで
はとくに生礁岩体のひろがりについて，貯油槽としての ポテンシャルを考慮しながら新たに別の分類をみること にする。

すなわち，大洋中にみられる海山に関係のあるような いわゆる孤島型生礁（以下孤島型と略す）が 1 つの典型 であり，他方，大陸ないしはある程度の大きさをもつ陸 島の縁に形成される陸縁型とがある。その中間的な存在 としては，海台型，陸棚型の 2 型をそれぞれの端成分寄 りにおいて設定することが可能であろら。

生礁の形成は，いうまでもなく基艋構造としての海底 面と，成長の上限をなす海水面との間に規制されて抗こ るものであり，そのため，第 1 期としての主たる上方伸 長の時期，そしてその後の側方への拡張期とを識別する ことができ，それが基本的な成長期区分であると同時に 成長成分を表わしていることにもなる（第 2 図）。

孤島型においては, 周辺からの陸源挽屑物の供給を絶 たれた孤立系としての生礁が形成されるので，塊状でし かもスカートの短い岩体となる。他方, 陸縁型では生礁 の一端が陸地に接するかそれに近い状態で成長するため に, 裾礁ないしは堡礁タイプの発展をとげる。したがっ てそのスカートは広く海底にのび，しばしばラグーン， バックリーフ・サイトあるいはインターリーフ・ベイス ンと呼ばれるよらな静水環境を伴う。また, 陸棚型と呼 ぶものは，水面まで露出する顥著な生礁とならず，いわ ば沖合相のサンゴ礁として，あるいはバンク（堆）状に あるいは層状に近く発展するもので，スカンジナビア半

第 2 図生礁の成長成分

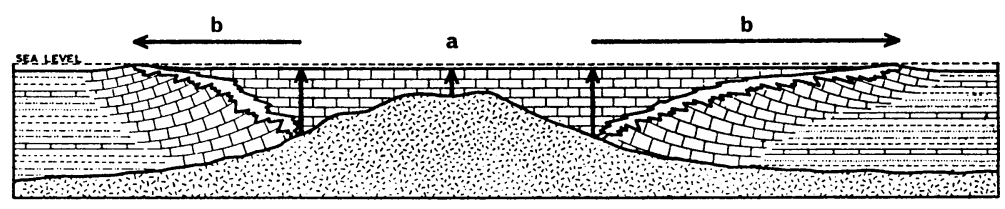

$\mathrm{a} ：$ 上方伸長

b : 側方伸長

(PLAYFORD \& LOWRY, 1966 に加筆)

(48) 
第 3 図生礁中の時間間隙形成 (solution unconformity).

(SCHLANGER, 1963 に加筆)

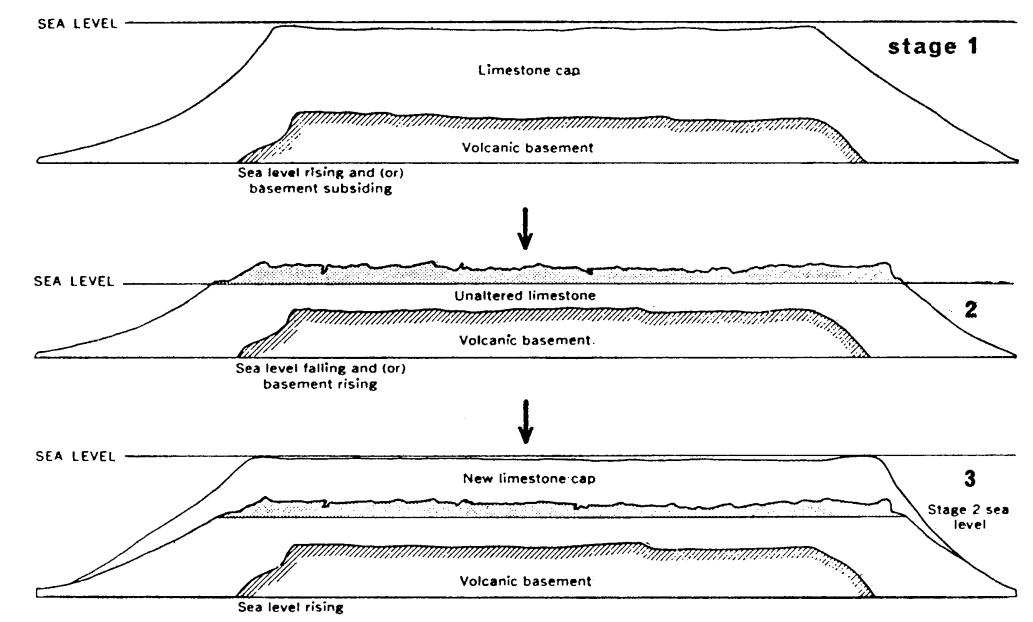

島周辺の北海に知られている “深海サンゴ堆”もこのタ イプの生礁の 1 つとみせよう。

長い地質時間の経過の中で, 海水面がまったく一定不 変であったといらことは考えにくい。気候変動や地壳の 運動に支配されて，何らかの海水準の変動があたっとみ るべきであろらから，それにつれて生礁岩体の成長がイ ンターミッテントになることは当然考慮されねばならな い。そのような生礁の成長停止期あるいは浸食期の表現 は，岩体中ではヒドンハイアタス，ダィアステム，不整 合といった形態となって見出されるであろう。海台型の ように上方伸長期よりも側方伸長期が長くなった，いわ ば頭打ちの生礁にとっては，このような海水準変動の影 響は最も大きく, 生礁上面がしばしば浸食の場に変わっ ている(第 3 図)。

こうした生礁中の時間間隌はいろいろの原因と期間を もち, 生带の欠如さ光見出されない程度に短いものもま た多く含まれているにちがいない。生層序学的には，生 带 (biozone) として認定されるだけの形態変化 (種進化) に必要な長さは，筆石やアンモナイトのように進化が速 いとされるものでさえ， 1 帯当り $30 \sim 100 \times 10^{4} \mathrm{y}$ と計算 されているから，それ以下の長さのハイアタスなどはよ ほど注意して構造的な差異でもみないかぎり，認定すら 困難であることのほうが多いであろう。まして，いま問 題にしているよらな生礁ではcarbonates on carbonates の 層序となるであろらから，その間の間吵を形態的に正し く認識するのは容易なことではない。

したがって，一般の生礁には数多くの時間帯欠如が含 まれているとみなすべきであり，生礁岩体トータルの厚 さは真の形成量ではなく（形成量一浸食量）の形で残 ったものと考えねばならない。いいかえれば，計算で求
第 4 図 秋吉石灰岩体の構成

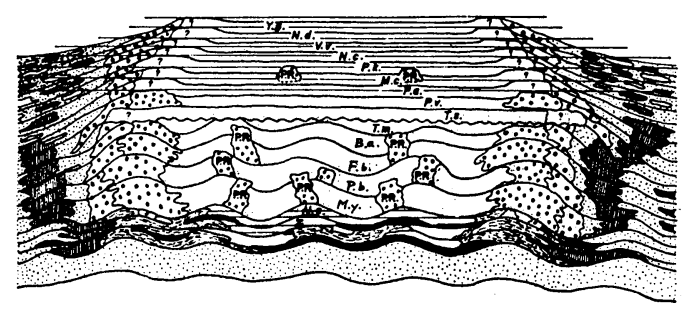

Y.s.: Yabeina shiraiwensis subzone

N.d.: Neoschwagerina douvillei subzone

V.v: Verbeekina verbeeki subzone

二 N.c.: Neoschwagerina craticulifera subzone

畳 P.k.: Parafusulina kaerimizensis subzone

系 M.c.: Misellina claudiae subzone

P.a.: Pseudofusulina ambigua subzone

P.v.: Pseudofusulina vulgaris subzone

T.s.: Triticites simplex subzone

T.m.: Triticites matsumotoi subzone

B.a.: Beedeina akiyoshiensis subzone

石 E.b.: Fusulina biconica subzone

炭 P.b.: Profusulinella beppensis subzone

系 M.y.: Millerella sp. subzone

N.s.: Nagatophyllum satoi subzone

Z.: Zaphrentoides sp. subzone

P.R.: patch reef facies

（太田, 1968, fig. 17ょり)

められる見かけ上の平均堆積速度は, 生礁の場合真の值 りよりもはるかに小さいことが多いはずである。逆に, 生礁自体の成長速度 $D$ は, 一般に構成単位の主体である サンゴ類各種の実測成長率，あるいはウーライトのよう な石灰質充填物の堆積速度などの実測値 $\Delta d$ を基礎に 計算したものとほとんどの場合一致しないのである。 わが国での具体例をあげてみよう。秋吉石灰岩（第 4 
図)の最下部は石炭紀前期の Zaphrentoides 帯（335× $10^{6} \mathrm{y}$ 前とみなす）であり,最上部は二畳紀後期の Yabeina shiraiwensis帯 $\left(250 \times 10^{6} \mathrm{y}\right.$ 前とする）とされ，石 灰岩体の厚さは総計約 $650 \mathrm{~m}$ と見積られている（太田， 1968)。したがって，計算上では $7.6 \mathrm{~cm} / 10^{4} \mathrm{y}$ となって， 極論すれば 100 年ごとの等時線がフズリナ殼を何本も横 切ってしまうほどの，実情からかけ離れた值が得られる ことになるのである。

この秋吉石灰岩体の場合, 二畳一石炭紀の境界付近に 微弱な構造変化が想定されているものの，それほど大き な欠如なしに各フズリナ帯が生層序学的に確認されてお りそれだけに，いか隠された時間間隙が大きな割合 を占めているかをよく認識することができる。このよう 㳊生礁の炭酸塩岩体の形成速度を求める作業が困難であ るのは，それほどに形成の歴史，とりわけ海水面付近で の形成, 浸食のくり返しの経緯が複雑であることを雄辨 飞物語っている。

\section{5. 生礁の周緑相}

培でに述べたように，生礁の形態は主として基盤，海 水面目位置, 陸源物質供給地からの隔離程度などの要因 によって規制されている。孤島型では，いかゆる環礁夕 イプの生礁が 1つの熟成型とみられ，そのスカートは礁 成砂岩等の粗い堆積物からなる急傾斜面（ときに $50^{\circ}$ に 達する例が知られている）をなして深い周辺の海底に遷 移する。これと対照的な周縁部を形成するのが陸棚型生 礁であり，この場合，礁自体の成層性も強く，スカート との区別もそれ汪ど明膫でないまま広く裾野をひいた成 層炭酸塩岩体ができあがる。周縁では多くの陸源研屑物 層と指交するのも特徴である。

陸縁型にはいくつもの亜型ないしは変型が識別される そちがいないが，大陸縁辺部につく裙礁や堡礁はその中 の代表的な発達様式で，明瞭な生礁突出地形をもつと同 時にスカートもまた広く発達する。オーストラリア東岸 の大堡礁 (Great Barrier Reef) はその大規模なるので あり，各個の生礁の海面近くの形態は海台型や孤島型を 想わせるが，周縁相が広いまったく異なっていて，浅い 海域の炭酸塩岩類, つまり礁源砕屑物が広いスカートを なすといら特徵がある。

孤島型と海台型とは，本質的には拈とらく同一とみて 差支光ないと思われる。しかし，熟成度といら点からみ ると後者がより老成して打り，したがって直接波浪を強 くから゙らない礁上面が広く発達する形態をもつにいた る。たび重なる浸食によって上面が著しく平坦化される と，僅かの海水準変動にようてもほとんど沈水してしま う場合もあり，もしその程度が著しいときには，一気に
礁形成が停止してしまうことすら考えられる。いずれに しても,こうした隔離タイプの生礁には大量の陸源物質 の供給はなく, 周縁相はしばしば急激に沖合相の堆積物 によって占められる。前出の秋吉台石灰岩の場合も復元 図によればそらした性格が強く現われている。

生礁周縁相として最も幅広い変異を示すのは，いらま でもなく陸縁型生礁である。列島に関連して形成される もののように，ある部分では孤島型や海台型と共通する 面をもち，あるときには生礁本体ときわめて区別しにく いパッチリーフと呼ぶ小規模生礁の散在をみるようにな ることも少なくない。

小さな陸縁型生礁においては, 礁の形成・発達段階の 原型を示唆するようないくつかの周縁相がみられる。例 えば，サンゴ類の発育程度でいらならば，周辺に向から につれて種数が減少するとともに，底質をカバーする割 合，すなわち被度が次第に小さくなる，といった種々の クラインを生じるのがふつうである。これはは，造礁性 サンゴ類の生態学的条件が好適である部分からそうでな い部分へ向かっての 1 つの傾斜であり, 生礁周緑相とし ては基本的に重要な現象であるとみてょい。

このよらなクラインを示す好例は, 関東一円の完新世 堆積物中に分布する沼サンゴ層やそれに対比される貝層 中に見出され，そこでは造礁性群体サンゴとしては最も 寛容度の大きいキクメイシモドキ(Oulastrea crispata) が，汽水域あるいは泥質底域，低水温域などにまで分布 乙, 造礁性生物の最外縁相，い小かえれば生礁の先兵役 をなすフロント相を形成している（浜田，1975；辻ら， 1976 ; HAMADA, 1977)。

また，造礁環境としては典型的でない泥底環境にあっ ては，いわゆる浮きサンゴがょく発達して，固定基盤上 でなくてもサンゴ類の群体が発育できることも明らかに なってきている。現在では日本列島南岸沿いの造礁サン ゴ生育地でよくみられるし，化石ではかつて典型的サン ゴ礁といわれたシルル紀のマッチ・ウェンロックやゴト ランドの礁のかなりの部分が，礁形成周辺相あるいは未 熟相としての浮きサンゴ相であるといわれるようにっな てきた(Аввотт，1975)。

造礁生物の発達は水温に大きく依存しているので，例 えば造礁性サンゴ類の属レベルでの多様性と水温との間 の相関はきわめて高い（第 5 図）ことが示され，生礁形 成の生態学的，とくに気候帯に関連した周縁相を知る 1 つの大きな手がかりとすることができる。

このよらなことは，生礁をとりまく堆積物についても またいえるのであって，中緯度高圧帯に発達する陸縁型 生礁の場合，堡礁がはるか沖合にまでのび，その内側に は通常のラグーンではなくて塩湖が形成されることがあ 
第 5 図造礁サンゴの属の゙多様性と年間最低海水温 との関係（インド洋に扣ける例）

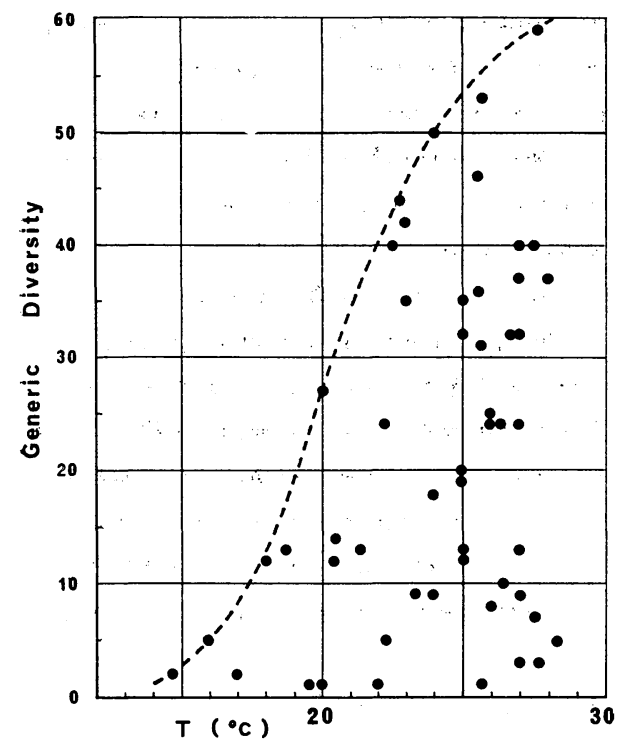

(STODDART \& YONGE, 1971 を簡略化)

り，地質学的にみれば大量の蒸発岩類が堆積する場とな る。こうした例は，いわゆる列島型の陸縁型生礁には少 なく，北米のナイアガラ相シルル紀生礁之蒸発岩層のよ らに，広大な大陸的陸縁生礁の場合に発達するものであ ることにも注意すべきであろう。

\section{6. 生礁における藻類の役割}

地史上で最初の生礁形態を現出せしめたのが，ストロ マトライト形成の主役である藍藻類であったことはす でに記したが，その後の地史にあって，化石ならびに現 生サンゴ礁の中で果たす藻類の役割もきわめて大きい。 それは，藻類が石灰藻のように直接生礁構造に参与する 形のみならず, 造礁性生物, とりわけ造礁性サンゴ類の 軟組織中の共生物として，礁構造の骨格を形成する補助 役を勤めたり，あるいは礁周辺の生物の飭として最も基 本的な 1 次生産者の位置を占めるなど，あらゆる面にお ける重要性を指摘できるのである。

一般に，藻類はクロロフィルによる光合成のために， 海中に打ける分布の階層性をみごとに保ち，したがって 環境指示物としての価值がきわめて高い。ところが；古 生態学の立場からみると, Lithothamnium とか Halimeda のよ5に石灰質を分泌して生礁構成に加わってい るものを除くと，ほとんど化石上の記録が失われてしま ら生物であるために，しばしばその価值が限定された り，不当に低く評価されたりすることになってしまう。

実際, 石灰岩中の化石藻類に関しては, 古くから個別
第 6 図海生生物硬質部门炭酸塭中に含まれる $\mathrm{MgCO}_{3}$.

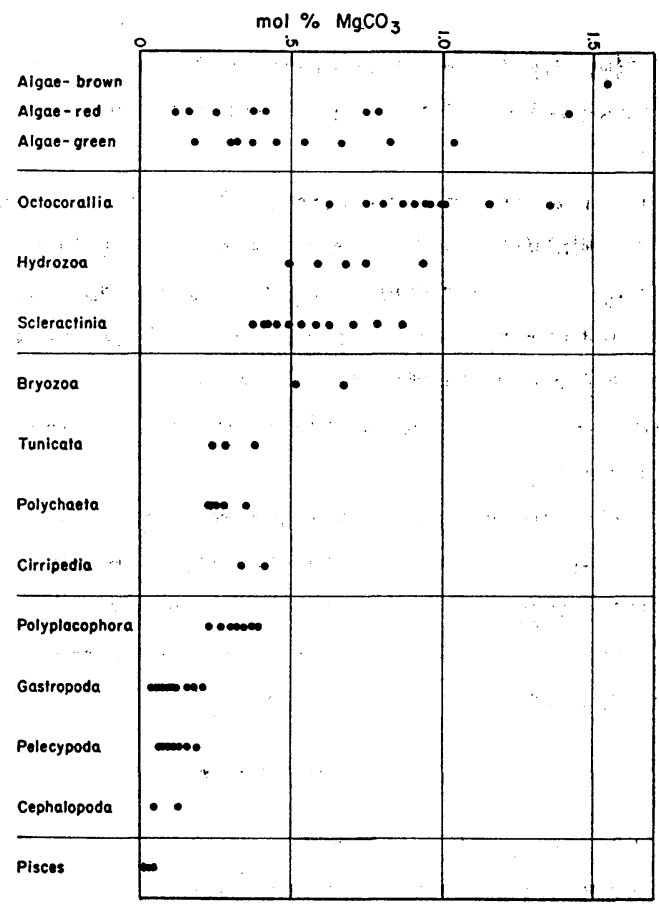

(LowENSTAM, 1963, fig, 8 に加筆)

第 7 図 $\exists$ ロッパの石灰藻古生態解析の例 A
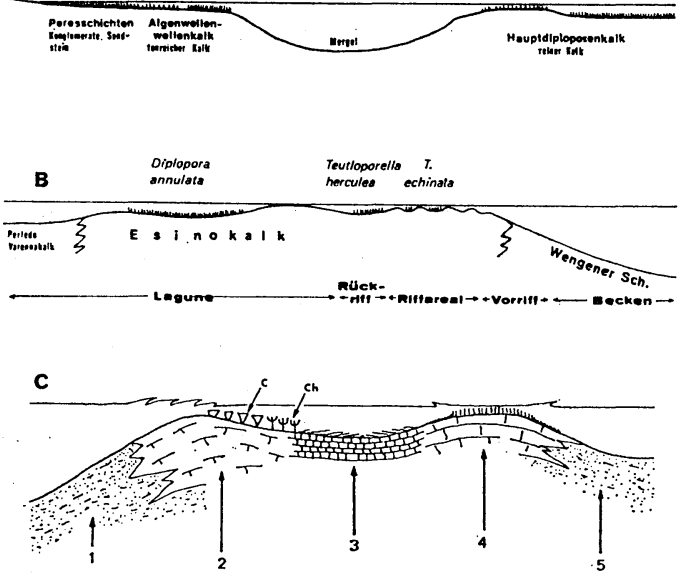

A：三畳紀アニシック（南チロル）の例 a : Diplopora hexaster グループ b : Physoporella-Oligoporella グループ c : Macroporella-Teutloporella グループ

B : 三畳紀ラディニック（グリグナ）の例 (ZORN, 1976, fig. 2 より)

C：石炭紀（ピレネー）の例 5,1 : 陸源物質, 2: サンゴ石灰岩, $3:$ Calcifolium-Ardengostella 石灰岩, 4 : カサノリ類 (Dasycladacea) 石灰岩, C: サソゴ類, Ch: Chaetetes 類

(PERRET \& VACHARD, 1977, fig. 3 より) 
の種の記載は多いけれども，それらを古生態学的ッール として生礁の構造解析や古環境復元に利用した例はそれ 注ど多くない。それは，1つには前述のよ5に残されな い藻類の方が抢そらく量的にはるかに多く，それを正し く加味できないとすれば，といら危惧を招くからでもあ ろう。

しかしながら，藻類中には通常の海生生物よりも $\mathrm{Mg}$ に富む炭酸塩からできているものも多いため（第 6 図）, 例えばドロマイト化作用などに関しては常に議論の対象 にとりあげられている。けれども，そのような場合にも， どちらかとい光ば地球化学的な立場からのアプローチが 主体であって，古生態学的な見方が比較的少ない恨みを なしとしない。

環境と石灰藻の種類との関係を重視した研究の実例と して, ヨーロッパの石炭紀ならびに三畳紀石灰岩体の解 析結果を引用して拈こう（第 7 図）。なお，ちなみにこ こではケーテテス類 (Chaetetida) を， サンゴ類として ではなく藻類類似生物として取扱っている。

\section{7. 生礁における変㬏}

生礁が決して形成のみの場でないことについてはすで にふれた。サンゴ類など造礁生物が著しい成長をとげる のと相まって，それらの破壊もまた常に進行しているの である。

物理的な面からの例をあげれば，地震とか津波のよう な偶発的な作用のほか，強い風浪などによっても生きた サンゴ群体がこわされることも多い。もちろん死んだ造 礁生物遺体，遺骸の破壊も著しいにはちがいないが，そ れには主として化学的な作用が大きく関与している。同 位元素を用いた実験でも，成長しているサンゴ群体にお いてさ光ポリプを失った基部などは直ちに周辺の海水 と化学反応を抢こし始めていることが証明されている。

生礁に打ける化学的作用として最も注目されるのは, 分解，溶解等による成分の移動であろう。この作用の結 果は, 続成作用の進行として堆積物や礁構造に反映され ることになる。ドロマイト化作用はいつもこうした例に 取り上げられるが，ここで注意しなければならないの は, 生礁における化学反応といらものは, ただ単に炭酸 塩と海水との反応といった単純な系として進むのではな く, 多くの，乙か子複雑な有機界西関与しつつ，その5 兄生体効果（vital effects）のようになかなか実体が明ら かにされない反応をも含んでいるために，その解析には いつも問題が残されているといらことである。

生礁の破壊要因として，これまで比較的軽視されてき たこがらとして他の生物による作用をあげることができ る。これは一括して生浸食 (bioerosion) と呼ばれ，最近
のリーフ・エコロジーの主題の 1 つにさえなっている。

例えば，礁構成の局所をとりあげてみても，穿孔性海 綿や藻類がほとんど常にはびこっていて，生礁全体の粒 度組成を小さくする方向へと作用し続けている。穿孔貝 (二枚貝, 巻貝), 蔓脚類 (フジッボ), 棘皮動物 (ウ 二）等も著しい破壊活動を行なっていることがよく認識 されるよらになってきた（大山，1977）。

生浸食は，骨格だけでなく生きたサンゴにも及んでお り，オニヒトデがポリプを食べる例は有名であるが，ブ ダイの仲間 (parrot fish) による剥食 (grazing)もそれに 劣ら始どの力をもっていることがわかってきている。

このような生浸食が他の破壊要因と重複し, 繰返し作 用することによって，生礁の破壊は粉化を軸にして進ん でいく。このような炭酸塩の粒度低下は, 当然海水との 反応を速めるのに役立ち, これが生礁や礁内外の堆積物 の速かな变質一続成作用に結びついてくることはいうま でもない。

生礁の分類でのべた型の違いもまた，変質作用に大き な意義をもつ。陸源物質の供給が少なく，ほとんぞ純粋 の炭酸塩フラクションだけからできている孤島型生礁で は，不溶残渣の少ない塊状石灰岩が形成されるととも に，各種成分の海水中への溶脱も速いため，できた石灰 中には注とんぞ有機質を含まないという特徴を具えるに いたる。同じ外洋性環境であっても海台型の場合には， 台地形のもつ広がりにしたがっていくつもの異なった变 質環境を生じ，それに応じた炭酸塩岩が形成されるであ ろう。すなわち，場所によってはウーライトを生じたり ドロマイト層ができたりして，より複雑な礁岩体をつく り出すことになる。

陸地に接しから外洋水といろいろの程度で関係する陸 縁型生礁においては，環境はより閉鎖的であり，変質作 用もと机に応じたタイプとなる。バックリーフ・サイト やインターリーフ・ベイスンをかかえる堡礁のような場 合，生礁自体からは種々の成分が溶脱していったとして も，地域全体としてみれば，それらが例党ば静水還元環 境に移動することによって収支を補いながら，ゲロスに は成分の偏在あるいは濃集といら結果を招くのである。

\section{8. 生礁での有機質の行方}

海の世界にあって最も生物の多椂性が高い生礁とその 周辺では, 当然それらの生体からもたらされる各種有機 物の生産量も莫大となることはいらまでもない。堆積物 として固定された化石生礁では，その生物遺構である礁 の枠組み (frame builders) や充填物 (infillings) のみ をみることになり，生時に生産された非固形有機質はほ とんど残されない。ふつう，化学的には炭酸塩と有機質 
とは天然の状態では結びつきにくく，有機質自体もほと んぞ大部分が無機化されてしまら。

しかしながら，本来生礁は無機物の量もさることなが ら，莫大な有機質を生産した母体であったことは疑いも なく，むしろ，その有機質の行方を探ることが大切であ ることはいらまでもない。石灭岩中に少量ではあるが残 存する遊離窒素と炭素との量をみると, 両者の間には大 へんに高い根関があり, 条件さえ整っていれば, 石灰岩 中にある程度の有機質を保持することは可能であるよう にみえる。おが国での例をあげるならば，赤坂石灰岩 (二畳系) 中にはケロゲンと思われる炭素化合物が相当 量含まれており（渡辺ら，1967；藤貫ら，1971；寺島 1976)，叮くと油臭がしたり，酸処理により油状の物質 が得られたりする。

生礁を構成する生物は固着・穿孔・匍匐等の生態をも つ，いわゆる底生生物 (benthos) が主体であり，それに 周辺を遊泳または浮遊する動植物が加わると考えてよ い。これらが死隇した場合を想定すると, 食物連鎖で消 費されるほか, 分解して各種成分にもどるといら過程が 考えられるよら。そのとき，もし適切な還元環境が与え られるならば，そのららの有機質の幾分かは油質にまで 変成する可能性は十分にある。

生礁とその周辺の生物から生時に排出される物質も決 して無視できる量ではない。前にも述べたように，外洋 に向かって開いた環境下においては，流出，溶脱等によ って失われてしまらであろらが，バックリーフやインタ ーリーフに出現する比較的閉錯した水塊中では，それら の蓄積が有意義に大きい。生態学的には違った例で必ず しも適切ではないが，広島湾におけるカキ棚での観察を 引用するならば， 8 月から翌年 4 月まで 9 力月間のマガ キ養殖期間中に，筏 1 台 $\left(200 \mathrm{~m}^{2}\right)$ から排泄される物質 は, 乾燥重量にして20 t 以上に達するという（荒川ら， 1972)。このよらな生物源堆積物 (biodeposits: 排泄物, 䔬 faeces十擬䔬 pseudofaeces）の例は, ヨーク川河口のア メリカガキについても報告があり， $1 \mathrm{ac}$ 当たり 25 万個 の群集密度で毎週 $981 \mathrm{~kg}$ もの排出粪塊が得られるという (HAVEN \& MoRAles-Alamo, 1976)。

生物からの排出物の化学組成は, それぞれの生物種に よってかなり違っているであろらが, 礁や礁周辺の微粒 堆積物にはこれらからの分解物が大量に混合して参与し ていることは疑いない。化石化しにくいし，仮に化石化 していても基質との判別が困難なこれらの物質について の研究はどらしてもおくれがちであり, 有機鉱床源とし ての性格付けもはっきりと定まっているわけではない。 しかしながら，そのような眼で, 生礁での有機質バラン スをより定量的に考察・研究する必要があることは否め
ない。

海中への有機質供給源としては，陸上・水中を問わず 生礁周辺に生育する顕花植物もまた考慮されるべきであ ろら。生礁がよく発達するような熱帯域における植物遺 骹の分解は速く，堆積物中にハイドロカーボンとしてど の程度移行しているかには疑問もあるが，ラグーン相と かバックリーフ相に伴らマングローブ・スウォンプや海 草域の生産性に注目しておくことは意義があると思われ る。

よく知られているよらに，マングローブ・スウォンプ 内の泥土は有機質含有量が高く, また分布面積も広いの で, 総量としての有機質供給能力は無視できないと思わ れる。ただし，マングローブ林はふつら熱帯域のなかで 生礁と淡水域との間を占める生態系であるとはいえ，熱 帯全域に均等に分布するものではない。インド洋での例 によれば，第 8 図に示すように，生礁形成域でありなが らマングローブ林のない地帯もあることは注目される。

第 8 図インド洋におけるマングローブ林発達域と 非マングローブ域

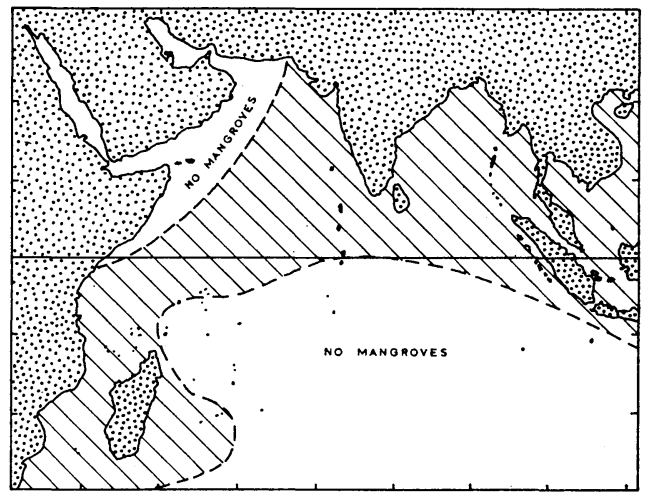

(STODDART, 1966 より単純化)

他方，海草の仲間は，種属によって気候帯とほぼパラ レルにきれいな帯状分布をする生態をもっている。これ らは化石として生礁やその周辺から見出されることはほ とんどないが，現在のサンゴ礁での例を参考にするなら ば，礁湖などにはかなり普遍的に分布するので，過去の 生礁にも重要な生態的位置を占め, 藻類などとともに直 接的な有機質供給源としての役割を果たしてきたと考え てよい。

なお，浮遊性微植物（phytoplankton）の生産性を海洋 全域について眺めると，そこには著しい周極構造が認め られ, もしこれらが将来の, あるいは過去のハィドロカ 一ボン鉱床に寄与するものであるとすれば，非熱帯域で の例えば中緯度以上の地域における地向斜型産油層形成 との関連を無視することはできない。ただし，ふつう微 
第 9 図浮遊性微植物の生産性

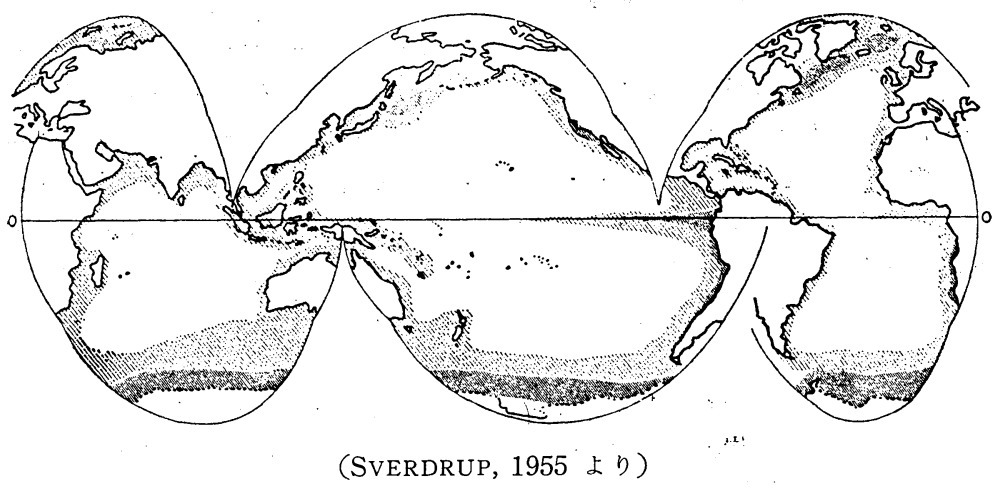

植物の生産性それ自体は 1 次生産者として動物の成長を 援けることに向けられるのであり，直接植物遺体が有機 質層となると考皇る必要はない。いずれにしても，いま とりあげている生礁とそれに関係のあるハイドロカーボ ン予想源と対照的な生態系が，気候帯に支配されながら 分布していることは強調しておきたい。

\section{9. あとがきに代えて}

一日本の石灰岩体の古生態学的位置分類一

以上，はなはだ大ざっぱではあったが，古生態学の立 場から（古）環境としての生礁を通観してきた。そこ で，それらをもとに既知の産油構造としての具体的な各 地の炭酸塩岩体ないしはそのリソロジー，あるいは周辺 の地質学的条件をふりか学ってみるとき，炭酸塩岩体一 般について，ある程度は生態型の位置づけのようなもの ができるのではないかと思われる。

筆者には，貯油槽としはての現場の炭酸塩岩体を手が けな経験がないので，具体的な判別や鑑定はできない。 がしかし，1つのラフな試案として，日本に打ける代表 的な石灰岩体をそのような観点から分類し，小論のまと めに代えたいと思う(第 2 表)。

従来, 地質学的, 生層序学的（とくに微化石等につい て）あるいは鉱床学的な検討を加えられた石灰岩体は多 く，現にいろいろの目的で稼行されている例も枚挙にい とまがない。ところが反面，グロスの古生態学的研究対 象として選ばれたものはそれほど多くない。また一方， 部分的, 局所的な古生物学的検討から㷌結される古生態 学的考察は若干ある。しかし, それらは該当する石灰岩 体からみれば余りにも小さく，果たして生礁形成環境の 議論にそのまま大きく寄与できるかどうかについては問 題も残る。

正しい古生態学的復元には, 可能な限り綿密にしてか つもれのない動植物相の解析が先行すべきことは論を俟 たないのであるが，不幸にしてわが国の炭酸塩岩体の古
第 2 表 日本の石灰岩体の古生態学的位置分類（試案）

\begin{tabular}{|c|c|c|c|c|}
\hline 地質時代 & 孤島型 & 海台型 & 陸棚型 & 陸縁型 \\
\hline $\begin{array}{ll}\text { 完 } & \text { 新 } \\
\text { 更 } & \text { 新 } \\
\text { 第 } & \text { 三 } \\
\end{array}$ & $\begin{array}{c}\text { 女神石灰岩 } \\
\text { (小規模) }\end{array}$ & $\begin{array}{l}\text { 琉球石灰岩 } \\
\text { (一部) }\end{array}$ & & $\begin{array}{l}\text { 沼隆起サン } \\
\text { 马層 } \\
\text { 朝戸石灰岩 } \\
\text { 琉球石灰岩 } \\
\text { (一部) }\end{array}$ \\
\hline $\begin{array}{l}\text { 白 亜 紀 } \\
\text { シュラ紀 } \\
\text { 三 畳 紀 }\end{array}$ & 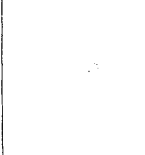 & & 岩宝山石灰 & $\left\{\begin{array}{l}\text { 鳥ノ巣石 } \\
\text { 灰岩 }\end{array}\right.$ \\
\hline $\begin{array}{l}\text { 二 胃 紀 } \\
\text { 石 炭 } \\
\text { デボン 紀 } \\
\text { テルル 紀 }\end{array}$ & $\begin{array}{l} \\
\text { 祇園山, 横會山石灰岩 } \\
\left(\mathrm{G}_{3}\right)\end{array}$ & $\begin{array}{l}\text { 葛生石兏岩 } \\
\text { 秋吉石灰岩 }\end{array}$ & & $\begin{array}{l}\text { 赤坂石灰岩 } \\
\text { 福地石灰岩 }\end{array}$ \\
\hline
\end{tabular}

生物学は, わずかの分類群についてのみ一応の手がつけ られたにすぎない。したがって，このような試みは本末 転倒でありことによっては行き過ぎのそしりをまぬが れないとは思われるのであるが，将来への発展の吒き台 として，あえて大胆に取りあげてみたわけである。さら に，本来ならばただ単に岩体の古生態にとどまらず，そ れをとりまく海況や古地理, とりわけ古緯度との関連, あるいはプレートの動さと関係せしめた石灰岩体の消長 などについても論ずべきであろろが，現段階においては それは屋上屋を重ねることになるのでとりあげないこと にした。諸賢からのご批判を賜われば幸いである。

\section{参考文 献}

Aввотт, B.M. (1975): Implications for the fossil record of modern carbonate bank corals. Bull. Geol. Soc. Amer., vol. 86, no. 2, pp. 203-204.

荒川好満, 楠木豊, 神垣正昭(1972): カキ養殖場におけ 
る生物源堆積現象 (Biodeposition) の研究 (I ), 養殖 適正密度について, Venus, 30巻 3 号, 113-128頁

Friedman, G.M. (1969 ed.): Depositional environments in carbonate rocks. Soc. Econ. Paleont. Mineral., Sp. Publ., no. 14, pp. 209.

Füchtbauer, H. (1969 ed.): Lithification of carbonate sediments, I, II. Sedimentol., vol. 12, nos. 1/2, $3 / 4$, pp. 322 .

藤貫 正, 米谷 宏, 西村富子(1971)：本邦石灰岩中の 炭化水素ガス拈よび有機態, 元素態炭素含有量, 岩鉱, 66 巻，5号，197-211頁

浜田隆士(1975)：日本の化石サンゴ礁一最古と最新の 2 , 3 の例を中心として一海洋科学, 7 巻, 599-606頁

HAMAdA, T. (1977): The Holocene corals of raised reefs of Japan. 2nd Symp. Intern. Cor. Récif. coral. foss., Paris, Sept. 1975. Mém. du Bur. Recher. géol min., no. 89, pp. 389-395̄.

Jell, P.A. \& Jell, J.S. (1976): Early Middle Cambrian corals from western New South Wales. Alcheringa, vol. 1, no. 2, pp. 181-195.

Jones, O.A. \& EndeAn, R. (1973 ed.): Biology and geology of coral reefs, vol. 1, geol. 1, Academic Press. 小西健二(1976)：サンゴ礁堆積物, 奈須紀幸編: 海洋学 講座 5, 海洋地質, 67-81頁

KUKAL, Z. (1971): Shallow-water carbonate sediments. in Geology of Recent Sediments, pp.343-375, Academic Press.

Logan, B.W., Rezak, R. \& Ginsburg, R.N. (19 64): Classification and environmental significance of algal stromatolites. Jour. Geol., vol. 72 , no. 1, pp. 6883.

Lowenstam, H.A. (1963): Biologic problems relating to the composition and diagenesis of sediments. in Donnelly, T.W. ed. The Earth Sciences, pp. 137195., Univ. Chicago Press.

Milliman, J.D. (1974): Marine carbonates. Recents Sedimentary Carbonates, part 1, 375 pp., SpringerVerlag.

太田正道(1968)：地向斜型生物礁複合体としての秋台石 灰岩層群, 秋吉台科学博物館報告, 第 5 号, 1-44面, $1-31$ 図版。

大山 㤬(1977)：サンゴ礁と石灰岩(1), 地質ニュース, 276号，38-44. 頁

Perret, M.F. et VAchard, D. (1977): Algues et pseudio-algues des calcaires Serpoukhoviens d'Ardengost (Hautes-Pyrénées). Ann. Paléont. (Invert.), t.
63, fas. 2, pp. 85-156.

STODdART, D.R. \& Yonge, M. (1971 ed.):Regional variation in Indian Ocean coral reefs. Symp. Zool. Soc. London, no. 28, 584pp.

寺島美南子 (1976)：炭酸塩岩中の有機物について, 地球 化学, 10 巻, 1 号, 41-44頁

辻誠一郎, 遠藤邦彦, 浜田隆士, 松岡敬二(1976): 千葉 県椿海低地帯に扣けるキクメイシモドキの産出につい

て, 第四紀研究, 5 巻, 3 号, 131-132頁

渡辺美南子, 阿部修治, 藤原鎮男(1967)：岐皁県赤坂石 灭岩中の炭素質物質について, 地球化学, 1 巻, 1 号 1-6頁

Wells, J.W. (1967): Corals as bathometers, Marine Geology, vol. 5, nos. 5/6, pp. 349-365.

Wilson, J. L. (1975) Carbonate facies in geological history, 471 pp., Springer-Verlag.

YounG, G.M. \& Long, D.G.F. (1976): Stromatolites and basin analysis: an example from the Upper Proterozoic of Northwestern Canada. Palaeogeogr. Palaeocl. Palaeoecol. vol. 19, pp. 303-318.

ZoRN, H. (1976): Über den Lebensraum fossiler Wirtelalgen in der Trias der Alpen. Naturwiss., Jahrg. 63, Hft. 9, pp. 426-429.

\section{睤 疑 応 答}

大嶋 アブダビで走査電顕像を見ていると，faecal pellets (排出翼) が出てくる。これは浅い波のエネルギ 一が高い所では皆くずれて他の堆積物に混ってしまう。 カキが大量の䔬を出すといらお話があったが，これはど んな堆積物としてでき，また実際どこにあるのかといら ことについて教えて頂きたい。

浜田 ご承知のよらにカキのよらな Mollusea 類は, 特殊な benthos で他の肉を喰っているものを除くと， scavenger か plankton feeder である。とくに reef は近 にいるものはじっとしていて入ってくるものを食べ糞を 出すといら生態なので，物質不隇の法則でみると溶液の 部分は別として固体部分はそこに留まることになる。 Faecal pellets といら以上当然肛門を持ち固形物を作る 内臓を持っている生物だけが出すわけだが，それ以外の ものもあるし, excretion は相当の量にのぼると思う。 ただし，おっしゃるように波の荒い所ではこわれるし，2 次的に排出物がまた食物になるといらことを考なくては ならない。カキの場合を単純計算すると数 $1,000 \mathrm{t}$ の量 が 1 年間に出るといらことになる。普通 lime mud とい われているもののかなりの部分がこのようなものを含ん でいるのではないだろらか。 
青柳 千葉では reef の泥質の部分についているサン ゴを見たが，これがお話にあった浮サンゴというもの か。

浜田 浮サンゴとは俗称であって，種類によらず形態 的・生態的なものをいっている。日本ではやはり沼サン ゴが浮サンゴの一番良い例といえる。つまり，固い基盤 がなくかつ lime mud の堆積速度に比べてサンゴの成長 が早いとさには，非常に平らになった base をもっった
浮サンゴができ上る。これは古生代でも福地の Devonian のような例がある。現世でも東京湾などに例がある。潮 岬近くの入汇では泥の上に浮いたサンゴが見られる。こ のようなものはアラビア湾とか紅海にもあることを聞い ている。この形態は普通の reef 形成の initiation を考 える上で大変役に立つし, reef margin の現象の $1 つ と$ してもかなり特徴的なものだといえる。 